\title{
Insect antimicrobial peptides: potential tools for the prevention of skin cancer
}

\author{
Miray Tonk ${ }^{1} \cdot$ Andreas Vilcinskas $^{1,2} \cdot$ Mohammad Rahnamaeian ${ }^{1}$
}

Received: 15 April 2016 /Revised: 27 June 2016 / Accepted: 29 June 2016 / Published online: 15 July 2016

(C) The Author(s) 2016. This article is published with open access at Springerlink.com

\begin{abstract}
Antimicrobial peptides/proteins (AMPs) are biologically active molecules with diverse structural properties that are produced by mammals, plants, insects, ticks, and microorganisms. They have a range of antibacterial, antifungal, antiviral, and even anticancer activities, and their biological properties could therefore be exploited for therapeutic and prophylactic applications. Cancer and cancer drug resistance are significant current health challenges, so the development of innovative cancer drugs with minimal toxicity toward normal cells and novel modes of action that can evade resistance may provide a new direction for anticancer therapy. The skin is the first line of defense against heat, sunlight, injury, and infection, and skin cancer is thus the most common type of cancer. The skin that has been exposed to sunlight is particularly susceptible, but lesions can occur anywhere on the body. Skin cancer awareness and self-efficacy are necessary to improve sun protection behavior, but more effective preventative approaches are also required. AMPs may offer a new prophylactic approach against skin cancer. In this mini review, we draw attention to the potential use of insect AMPs for the prevention and treatment of skin cancer.
\end{abstract}

Mohammad Rahnamaeian

mohammad.rahnamaeian@uni-giessen.de

Miray Tonk

miray.tonk@ime.fraunhofer.de

Andreas Vilcinskas

andreas.vilcinskas@agrar.uni-giessen.de

1 LOEWE Center for Insect Biotechnology and Bioresources, Fraunhofer Institute for Molecular Biology and Applied Ecology, Winchester Strasse, 35394 Giessen, Germany

2 Institute for Insect Biotechnology, Justus Liebig University of Giessen, Heinrich-Buff-Ring 26-32, 35392 Giessen, Germany
Keywords Antimicrobial peptides · Prophylaxis · Skin cancer $\cdot$ Cosmetic industry $\cdot$ Sun cream

\section{Introduction}

Despite efforts to develop effective new treatments, cancer remains the second most common cause of death in the world (Siegel et al. 2014). The worldwide occurrence of cancer is increasing, and in the case of skin cancer, one relevant factor is the prolonged exposure of the skin to the sun during normal daily activities or as a leisure pursuit, resulting in high doses of ultraviolet (UV) radiation (Holm 2014; Palanki et al. 2015). UV radiation from artificial sources, such as tanning beds and sunlamps, provides additional exposure scenarios (Palanki et al. 2015). General risk factors for skin cancer include lack of skin pigmentation, lesions such as moles, and compromised immunity caused by immunosuppressive medication (e.g., for organ transplants) or the presence of HIV/AIDS (Cakir et al. 2012; Chiao and Krown 2003; Eide et al. 2013; Iannacone et al. 2015; Zhu et al. 2015).

Approximately 3.5 million people are diagnosed with skin cancer annually in the USA (Robinson 2005; Rogers et al. 2010). There are three major types of skin cancer: basal cell carcinoma, squamous cell carcinoma, and malignant melanoma (Stern 2010). Basal cell carcinoma is the most common type, but it is also the least dangerous if detected early. It involves cells from the deeper layers of skin, usually in parts of the body that are exposed to the sun, such as the face, head, neck, ears, shoulders, and back, with most cases occurring on the face (Gordon and Carucci 2013; Telfer et al. 2008). Squamous cell carcinoma is the second most common type, involving cells of the upper skin layers, and is more likely to spread to areas under the skin. It commonly occurs on the legs and feet but may develop elsewhere (Ogden and Telfer 2009). 
Melanoma is the least common cancer of the skin but is among the most aggressive of known cancers (Vera et al. 2015). It can occur anywhere on the skin but is more likely to develop on the back or legs, and although curable in its early stages, the later-stage tumors often become drug resistant and therefore recalcitrant to chemotherapy (Korotkov and Garcia 2012; Ogden and Telfer 2009; Riedl et al. 2011a). Exposure to sun increases the risk of all three main types of skin cancer (Gallagher et al. 2010), but exposure during childhood is particularly harmful in the case of melanomas and basal cell carcinomas (Stewart and Wild 2014).

Skin cancer therapy involves the careful selection of one or more modalities, including surgery, radiotherapy and chemotherapy. Current drugs for such indications are insufficiently selective, resulting in deleterious effects against non-target cells, particularly those that normally divide rapidly (Al-Benna et al. 2011; Kalyanaraman et al. 2002), resulting in symptoms such as alopecia, rashes, vomiting, and even myelosuppression (Ferguson and Pearson 1996; Harris et al. 2013; Sanderson et al. 1996). Many tumors ultimately become resistant to conventional chemotherapy due to the selection of multidrugresistant cells (Zahreddine and Borden 2013). It is therefore imperative to find new products with novel modes of action, such as cytotoxic antimicrobial peptides and proteins (AMPs) (Chamorro et al. 2009; Koczulla and Bals 2003).

AMPs have been developed as alternatives for the treatment of infectious diseases. Such peptides are produced naturally by nearly all organisms as a part of the innate immune system (Rahnamaeian et al. 2016; Tonk et al. 2014), and due to their broad antimicrobial spectrum, they are often described as natural antibiotics (Bolouri Moghaddam et al. 2015). Several insect AMPs also show cytotoxic effects against diverse cancer cell lines, such as mouse myeloma, melanoma, lymphoma, leukemia, breast cancer, and lung cancer (Iwasaki et al. 2009; Kang et al. 2012; Kim et al. 2013; Xiao et al. 2006). These anticancer peptides (ACPs) are characterized by high therapeutic efficacy, a low probability of resistance emerging in target cells, and limited or no toxicity against mammalian erythrocytes, macrophages, and fibroblasts (Barbault et al. 2003; Saido-Sakanaka et al. 2004; Yamada et al. 2005). ACPs are also easy to synthesize and modify, they penetrate tumors efficiently, and they are biocompatible (Borghouts et al. 2005; Thayer 2011). On the other hand, they are also immunogenic and susceptible to peptidase activity and clearance through the kidneys, reducing their effective therapeutic half-life in vivo and making them more appropriate for topical applications (McGregor 2008; Rahnamaeian and Vilcinskas 2015; Wiesner and Vilcinskas 2010).

Although the activity of insect ACPs against skin cancer has not been studied in detail, proof-of-principle studies involving the topical application of ACPs from other sources have been successful. Rodrigues et al. (2008) showed that gomesin from hemocytes of the spider Acanthoscurria gomesian can arrest the growth of murine melanoma
B16F10-Nex2 cells when administered topically in a creambased formulation. Also, Gerashchenko et al. (2014) showed that human $\beta$-defensin 2 (hBD-2) can inhibit the growth of human carcinoma cells by suppressing the expression of BRaf, cyclin D1, and cyclin E, inducing the expression of $\mathrm{p} 21^{\mathrm{WAF} 1}$ and activating $\mathrm{pRB}$. The greater abundance of negatively charged membrane components such as sialic acid, phosphatidylserine and heparan sulfate makes cancer cells attract certain cationic amphipathic peptides (Wang et al. 2016; Riedl et al. 2011b). Particularly, phosphatidylserine in cancer cell membranes is targeted by temporin-1CEa, an AMP from the Chinese brown frog Rana chensinensis (Wang et al. 2016). Temporin-1CEa induces cell death in breast cancer cells by releasing pro-apoptotic factors from the mitochondria and also disrupts the plasma membrane by exposing phosphatidylserine, increasing plasma membrane permeability, and inducing membrane depolarization (Wang et al. 2013).

The active motifs of ACPs are short, so large-scale synthesis is cost-effective. Certain ACPs not only show intrinsic anticancer activity but also enhance the potency of conventional drugs (Gaspar et al. 2013; Hancock et al. 2006; Silva et al. 2012). There are currently 196 entries in the Antimicrobial Peptide Database (APD) (http://aps.unmc. edu/AP/database/antiC.php) describing peptides with anticancer activity. Most ACPs achieve cell membrane disruption by lytic activity or induce apoptosis in cancer cells through mitochondrial damage, in many cases leaving normal mammalian cells unharmed (Coffelt and Scandurro 2008; Hilchie et al. 2011). This review discusses the targets and active mechanisms of ACPs and highlights their potential as both prophylactic and therapeutic reagents indicated for the prevention and treatment of cancer. We also consider the potential inclusion of ACPs in cosmetics and personal care products, especially sun protection creams that could enhance protection against skin cancer by eliminating nascent cancer cells before symptoms become evident.

\section{The structure of ACPs}

Insect AMPs are cationic and amphipathic, and although the length, sequence and structure may vary, most have a comparatively low molecular mass ( $\geq 10 \mathrm{kDa})$. The structure includes hydrophilic and hydrophobic regions, and the net charge is highly positive (Dennison et al. 2006). The structure of AMPs allows strong electrostatic binding with bacterial or fungal cell membranes and certain enveloped viruses (Hoskin and Ramamoorthy 2008; Reddy et al. 2004), but ACPs also have the unique ability to bind cancer cell membranes. Most ACPs contain six cysteine residues forming three intramolecular disulfide bonds that assemble into hairpin like $\alpha$ helices, $\beta$-sheets, or mixed structures, but some extended 
structures have also been reported (Bulet and Stocklin 2005; Hoskin and Ramamoorthy 2008; Wang et al. 2013).

\section{The activity of ACPs}

AMPs can be assigned to different classes according to their diverse physicochemical properties, but only two general modes of action have been described: membranolytic and nonmembranolytic (Schweizer 2009). The activity of ACPs depends on their physicochemical characteristics, such as the primary sequence, secondary structure, net electric charge, amphipathicity, hydrophobicity, and concentration, as well as the composition of the target membrane (Adams et al. 2009; Reddy et al. 2004; Teixeira et al. 2012). The ability of many AMPs to permeabilize cell membranes correlates with their antimicrobial activities, e.g., in the case of defensins and cecropins (Rahnamaeian 2011). Membrane disruption by AMPs may involve pore formation (barrel-stave and toroidal pore models), membrane thinning, membrane dissolution (carpet-like model), or lipid-peptide domain formation. In other cases, AMPs bind to intracellular targets in the pathogen including nucleic acids and proteins (Bechinger and Lohner 2006; Brogden 2005; Chan et al. 2006; Papo and Shai 2005; Rahnamaeian et al. 2015; Yeaman and Yount 2003). Certain AMPs also display immunomodulatory activities (Jerala and Porro 2004; McPhee et al. 2005) such as the stimulation of chemokine and cytokine production and leukocyte chemotaxis (Bowdish et al. 2005). The ability of ACPs to kill tumor cells is poorly understood, although both membranolytic and non-membranolytic mechanisms may be involved. For example, several AMPs that interact with and disrupt negatively charged bacterial membranes (Hancock and Chapple 1999; Merrifield et al. 1995) can also kill mammalian cancer cells by inducing membrane permeability or apoptosis (Iwasaki et al. 2009; Papo and Shai 2005). ACPs are also able to lyse the tumor cells by inducing the blebbing and permeabilization of the membrane after binding directly to plasma membrane phospholipids such as phosphatidylinositol 4,5bisphosphate ( $\left.\mathrm{PIP}_{2}\right)$ (Poon et al. 2014).

The membranolytic activity of ACPs depends on the intrinsic characteristics of the peptide as well as the properties of the target membrane (Mulder et al. 2013). Also, the selectivity of some ACPs against cancer cells depends on the net negative charge of the membrane (Gaspar et al. 2013). Anionic molecules (phosphatidylserines, glycoproteins, glycosaminoglycans, heparan sulfate, $O$-glycosylated mucins, and sialylated gangliosides) confer a net negative charge on the membranes of cancer cells, in contrast to the typically zwitterionic membranes of normal cells (Giuliani et al. 2007; Hoskin and Ramamoorthy 2008; Raz et al. 1980; Schweizer 2009; Utsugi et al. 1991). The mode of action may involve electrostatic interactions between cationic peptides and the anionic components of cancer cell membranes (Kim et al. 2013). The same "carpet-like" and "barrel-stave" models that explain the interaction between AMPs and bacterial membranes can therefore also be invoked to describe interactions with cancer cells (Oren and Shai 1998; Pouny and Shai 1992; Schweizer 2009). Additional membranolytic events involve the permeabilization and swelling of mitochondria, followed by the release of cytochrome $\mathrm{c}$ and the induction of apoptosis (Mai et al. 2001).

Although the rapid killing of cells by ACPs may indicate the prevalence of a non-receptor-mediated mode of action, some non-membranolytic activities have also been described (Sharma 1992; Wachinger et al. 1998; Winder et al. 1998). These include the inhibition of angiogenesis, which is essential for the formation of tumor-associated vasculature (Schweizer 2009). Peptides can block the function of receptors expressed on angiogenic endothelial cells and thus perturb the formation of the tumor-associated vasculature (Arap et al. 1998; Lee et al. 2011; Mader and Hoskin 2006; Rosca et al. 2011; Schweizer 2009). The primary objective of antiangiogenic therapy is to normalize the tumor vasculature instead of reducing the density of tumor blood vessels (Shang et al. 2012). The development of therapeutic molecules which, individually or in combination with other reagents, target several aspects of angiogenesis might prove fruitful for cancer treatment in the future (Rosca et al. 2011).

\section{Impact of insect AMPs on cancer}

Insects comprise $\sim 55 \%$ of total biodiversity and $\sim 85 \%$ of animal biodiversity (Chernysh et al. 2002) and therefore provide a large potential source of ACPs. Only a few AMPs have been identified as ACPs based on in vivo testing, although others have been tested against tumor cell lines (Table 1). Insect-derived ACPs have not been tested directly against skin cancer cells, but as stated above, Rodrigues et al. (2008) successfully showed that the spider peptide gomesin was effective against subcutaneous murine B16F10-Nex2 melanoma cells when administered topically. The efficacy of insect ACPs against other types of cancer cells provides evidence that they should also be active against skin cancer. For example, cecropin B from Hyalophora cecropia increased the survival of mice bearing ascitic murine colon adenocarcinoma cells (Moore et al. 1994). Alloferon 1 isolated from bacteria-challenged larvae of the blow fly Calliphora vicina was able to stimulate NK cell activity and interferon (IFN) synthesis in animal and human models and could enhance antiviral and antitumor activity in mice (Chernysh et al. 2002). The harmoniasin analog HaA4 was found to be cytotoxic toward human leukemia cell lines such as U937 and Jurkat cells by inducing both caspasedependent apoptosis and necrosis (Kim et al. 2013). Dpeptides $\mathrm{A}, \mathrm{B}, \mathrm{C}$, and $\mathrm{D}$, designed and synthesized based on the sequences of 43-mer defensins from two beetles, were able to inhibit the growth of several cancer cell lines with different 


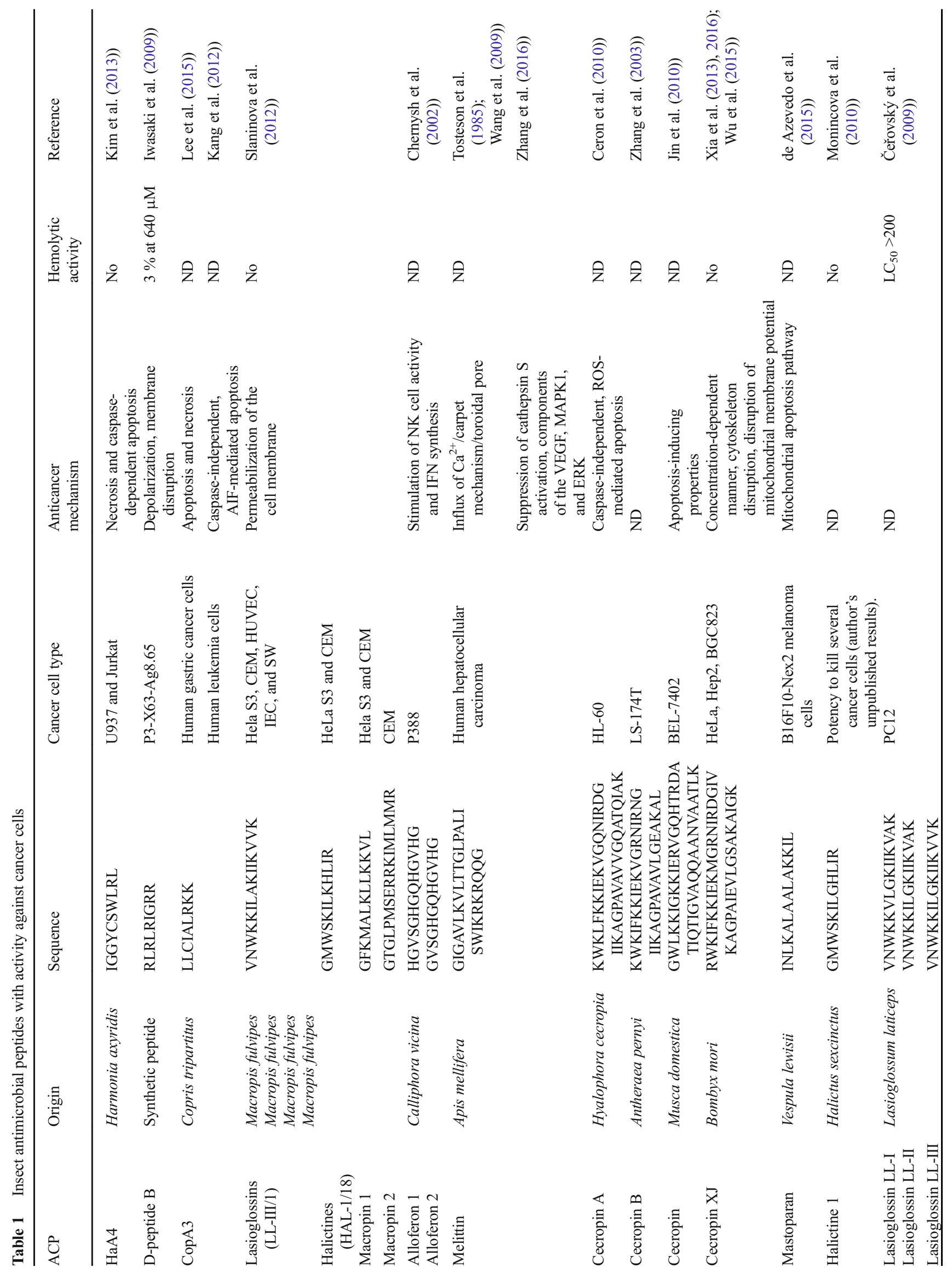




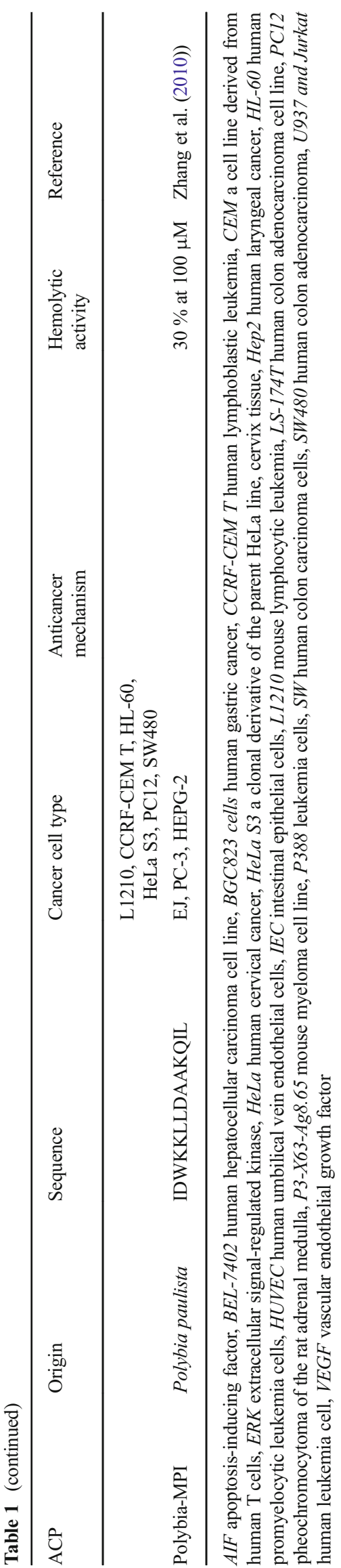

levels of efficacy, and D-peptide B showed the most selective activity against the mouse myeloma cell line P3-X63-Ag8.653. Flow cytometry and scanning electron microscopy revealed that this peptide disrupts myeloma membrane construction but has no effect against normal leukocytes. In addition, combinations of D-peptide B and dexamethasone showed synergistic activity against a mouse myeloma cell line (Iwasaki et al. 2009). These peptides are therefore promising candidates for novel anticancer drugs.

\section{AMPs as prophylactic anticancer ingredients in cosmetics}

As stated above, skin cancer can often be cured by surgery and/ or chemotherapy following an early diagnosis, although both approaches carry a moderate risk of recurrence (Guerra-Rosas and Álvarez-Borrego 2015). However, skin cancer is also one of the easiest diseases to prevent, because exposure to UV radiation can be limited not only by wearing appropriate clothing and staying indoors, but also by applying barrier creams that block the most dangerous wavelengths of UV radiation. The success of such approaches depends on the compliance of an informed at-risk population, because even the strongest barrier creams have a limited effective duration of activity. Therefore, the development of novel products that provide additional protection would reduce the incidence of skin cancer even further. Endogenous AMPs are produced in the human skin, so additional peptides with broader properties (including anticancer activity) could be used not only as a therapeutic intervention but also as a prophylactic measure to counteract cancer cell development by including the peptides in barrier creams, ointments, functionalized wound dressings, and cosmetics.

\section{Challenges of insect AMPs}

Although AMPs from insects and other sources could be developed into new products for the prevention and treatment of cancer, one challenge is the high cost of synthesis because many AMPs are long and contain disulfide bridges. However, the anticancer activity of AMPs is likely to resolve to certain motifs, and if these motifs can be identified, they could be produced in the context of a smaller artificial peptide. Furthermore, different AMPs can complement each other via potentiating interactions including synergy (Rahnamaeian et al. 2016; Bolouri Moghaddam et al. 2016). Therefore, hybrid peptides containing functional motifs from different AMPs could achieve greater therapeutic efficacy. Another concern is the hemolytic activity of some AMPs, and peptide engineering would be necessary to maximize their anticancer activity while minimizing hemolysis, e.g., by increasing the positive charge and hydrophobicity as well as changes in the spatial 
configuration of particular amino acids (Rahnamaeian and Vilcinskas 2015). The pH sensitivity of cationic AMPs also affects their activity, so the $\mathrm{pH}$ and ionic strength of the carrier matrix must be optimized to achieve the greatest efficacy.

\section{Concluding remarks}

AMPs have drawn the attention of the pharmaceutical industry because they represent a promising next generation of drugs with different modes of action compared to current antitumor agents. The latter tend to have severe side effects and encourage the development of resistant cell populations. AMPs offer a number of advantages over contemporary drugs and anticancer vaccines, including their potent activity at low concentrations, their high specificity (hence low toxicity toward normal cells), and the ability to produce them as costeffective synthetic or recombinant peptides, particularly short AMPs without disulfide bonds. AMPs provide a promising source of new drugs for the prevention and treatment of skin cancer because they are highly suitable for topical application and can be formulated as creams and ointments, which are suitable for self-administration or for parents to apply to their children.

\begin{abstract}
Acknowledgments The authors would like to acknowledge generous funding by the Hessen State Ministry of Higher Education, Research and the Arts (HMWK) via the "LOEWE Center for Insect Biotechnology and Bioresources" and from the Federal Ministry of Education and Research (BMBF) via the project Triple-In (Insect-derived anti-infectives from Indonesia, 16GW0126). We thank Dr. Richard M. Twyman for editing the manuscript.
\end{abstract}

\section{Compliance with ethical standards}

Funding This study was funded by the Hessen State Ministry of Higher Education, Research and the Arts (HMWK) via the "LOEWE Center for Insect Biotechnology and Bioresources" and from the Federal Ministry of Education and Research (BMBF) via the project Triple-In (Insect-derived anti-infectives from Indonesia, 16GW0126).

Conflict of interest The authors declare that they have no conflict of interest.

Ethical approval This article does not contain any studies with human participants performed by any of the authors.

Open Access This article is distributed under the terms of the Creative Commons Attribution 4.0 International License (http:// creativecommons.org/licenses/by/4.0/), which permits unrestricted use, distribution, and reproduction in any medium, provided you give appropriate credit to the original author(s) and the source, provide a link to the Creative Commons license, and indicate if changes were made.

\section{References}

Adams JS, Ren S, Liu PT, Chun RF, Lagishetty V, Gombart AF, Borregaard N, Modlin RL, Hewison M (2009) Vitamin D-directed rheostatic regulation of monocyte antibacterial responses. J Immunol 182(7):4289-4295. doi:10.4049/jimmunol.0803736

Al-Benna S, Shai Y, Jacobsen F, Steinstraesser L (2011) Oncolytic activities of host defense peptides. Int J Mol Sci 12(11):8027-8051

Arap W, Pasqualini R, Ruoslahti E (1998) Cancer treatment by targeted drug delivery to tumor vasculature in a mouse model. Science 279(5349):377-380

de Azevedo RA, Figueiredo CR, Ferreira AK, Matsuo AL, Massaoka MH, Girola N (2015) Mastoparan induces apoptosis in B16F10Nex2 melanoma cells via the intrinsic mitochondrial pathway and displays antitumor activity in vivo. Peptides 68:113-119

Barbault F, Landon C, Guenneugues M, Meyer J-P, Schott V, Dimarcq JL, Vovelle F (2003) Solution structure of Alo-3: a new knottin-type antifungal peptide from the insect Acrocinus longimanus. Biochemistry 42(49):14434-14442

Bechinger B, Lohner K (2006) Detergent-like actions of linear amphipathic cationic antimicrobial peptides. Biochim Biophys Acta Biomembr 1758(9):1529-1539

Bolouri Moghaddam MR, Tonk M, Schreiber C, Salzig D, Czermak P, Vilcinskas A, Rahnamaeian M (2016) The potential of the Galleria mellonella innate immune system is maximized by the copresentation of diverse antimicrobial peptides. Biol Chem. doi:10.1515/hsz-2016-0157

Bolouri Moghaddam MR, Vilcinskas A, Rahnamaeian M (2015) Cooperative interaction of antimicrobial peptides with the interrelated immune pathways in plants. Mol Plant Pathol 17(3):464-471. doi:10.1111/mpp.12299

Borghouts C, Kunz C, Groner B (2005) Current strategies for the development of peptide-based anti-cancer therapeutics. J Pept Sci 11(11):713-726

Bowdish DM, Davidson DJ, Hancock R (2005) A re-evaluation of the role of host defence peptides in mammalian immunity. Curr Protein Pept Sci 6(1):35-51

Brogden KA (2005) Antimicrobial peptides: pore formers or metabolic inhibitors in bacteria? Nat Rev Microbiol 3(3):238-250. doi:10.1038/nrmicro1098

Bulet P, Stocklin R (2005) Insect antimicrobial peptides: structures, properties and gene regulation. Protein Pept Lett 12(1):3-11

Cakir BÖ, Adamson P, Cingi C (2012) Epidemiology and economic burden of nonmelanoma skin cancer. Facial Plast Surg Clin North Am 20(4):419-422

Ceron JM, Contreras-Moreno J, Puertollano E, de Cienfuegos GA, Puertollano MA, de Pablo MA (2010) The antimicrobial peptide cecropin A induces caspase-independent cell death in human promyelocytic leukemia cells. Peptides 31(8):1494-1503

Čeřovský V, Buděšínský M, Hovorka $O$, Cvačka J, Voburka Z, Slaninová J (2009) Lasioglossins: three novel antimicrobial peptides from the venom of the eusocial bee Lasioglossum laticeps (Hymenoptera: Halictidae). Chembiochem 10:2089-2099

Chamorro CI, Weber G, Gronberg A, Pivarcsi A, Stahle M (2009) The human antimicrobial peptide LL-37 suppresses apoptosis in keratinocytes. J Invest Dermatol 129(4):937-944. doi:10.1038 jiid.2008.321

Chan DI, Prenner EJ, Vogel HJ (2006) Tryptophan-and arginine-rich antimicrobial peptides: structures and mechanisms of action. Biochim Biophys Acta Biomembr 1758(9):1184-1202

Chernysh S, Kim SI, Bekker G, Pleskach VA, Filatova NA, Anikin VB, Platonov VG, Bulet P (2002) Antiviral and antitumor peptides from insects. Proc Natl Acad Sci U S A 99(20):12628-12632. doi:10.1073/pnas. 192301899 
Chiao EY, Krown SE (2003) Update on non-acquired immunodeficiency syndrome-defining malignancies. Curr Opin Oncol 15(5):389-397

Coffelt SB, Scandurro AB (2008) Tumors sound the alarmin(s). Cancer Res 68(16):6482-6485. doi:10.1158/0008-5472.CAN-08-0044

Dennison SR, Whittaker M, Harris F, Phoenix DA (2006) Anticancer alpha-helical peptides and structure/function relationships underpinning their interactions with tumour cell membranes. Curr Protein Pept Sci 7(6):487-499

Eide MJ, Asgari MM, Fletcher SW, Geller AC, Halpern AC, Shaikh WR, Li L, Alexander GL, Altschuler A, Dusza SW (2013) Effects on skills and practice from a web-based skin cancer course for primary care providers. J Am Board Fam Med 26(6):648-657

Ferguson LR, Pearson AE (1996) The clinical use of mutagenic anticancer drugs. Mutat Res 355(1-2):1-12

Gallagher RP, Lee TK, Bajdik CD, Borugian M (2010) Ultraviolet radiation. Chronic Dis Can 29(Suppl 1):51-68

Gaspar D, Veiga AS, Castanho MA (2013) From antimicrobial to anticancer peptides. A review. Front Microbiol 4:294. doi:10.3389 /fmicb.2013.00294

Gerashchenko O, Zhuravel E, Skachkova O, Khranovska N, Pushkarev V, Pogrebnoy P, Soldatkina M (2014) Involvement of human betadefensin-2 in regulation of malignant potential of cultured human melanoma cells. Exp Oncol 36(1):17-23

Giuliani A, Pirri G, Nicoletto S (2007) Antimicrobial peptides: an overview of a promising class of therapeutics. Open Life Sci 2(1):1-33

Gordon SE, Carucci JA (2013) Skin cancer in immunosuppressed patients. Facial Plast Surg 29(5):402-410

Guerra-Rosas E, Álvarez-Borrego J (2015) Methodology for diagnosing of skin cancer on images of dermatologic spots by spectral analysis. Biomed Opt Express 6(10):3876-3891

Hancock RE, Chapple DS (1999) Peptide antibiotics. Antimicrob Agents Chemother 43(6): 1317-1323

Hancock RE, Brown KL, Mookherjee N (2006) Host defence peptides from invertebrates emerging antimicrobial strategies. Immunobiology 211(4):315-322. doi:10.1016/j.imbio.2005.10.017

Harris F, Dennison SR, Singh J, Phoenix DA (2013) On the selectivity and efficacy of defense peptides with respect to cancer cells. Med Res Rev 33(1):190-234

Hilchie AL, Doucette CD, Pinto DM, Patrzykat A, Douglas S, Hoskin DW (2011) Pleurocidin-family cationic antimicrobial peptides are cytolytic for breast carcinoma cells and prevent growth of tumor xenografts. Breast Cancer Res 13(5):R102. doi:10.1186/bcr3043

Holm RP (2014) Skin cancer prevention and screening. South Dakota medicine: the Journal of the South Dakota State Medical Association 75-7: 79-81

Hoskin DW, Ramamoorthy A (2008) Studies on anticancer activities of antimicrobial peptides. Biochim Biophys Acta 1778(2):357-375. doi:10.1016/j.bbamem.2007.11.008

Iannacone MR, Pandeya N, Isbel N, Campbell S, Fawcett J, Soyer HP, Ferguson L, Davis M, Whiteman DC, Green AC (2015) Sun protection behavior in organ transplant recipients in Queensland, Australia. Dermatology 231(4):360-366. doi:10.1159/000439428

Iwasaki T, Ishibashi J, Tanaka H, Sato M, Asaoka A, Taylor D, Yamakawa M (2009) Selective cancer cell cytotoxicity of enantiomeric 9-mer peptides derived from beetle defensins depends on negatively charged phosphatidylserine on the cell surface. Peptides 30(4):660-668. doi:10.1016/j.peptides.2008.12.019

Jerala R, Porro M (2004) Endotoxin neutralizing peptides. Curr Top Med Chem 4(11):1173-1184

Jin X, Mei H, Li X, Ma Y, Zeng AH, Wang Y, Lu X, Chu F, Wu Q, Zhu J (2010) Apoptosis-inducing activity of the antimicrobial peptide cecropin of Musca domestica in human hepatocellular carcinoma cell line BEL-7402 and the possible mechanism. Acta Biochim Biophys Sin 42(4):259-265
Kalyanaraman B, Joseph J, Kalivendi S, Wang S, Konorev E, Kotamraju S (2002) Doxorubicin-induced apoptosis: implications in cardiotoxicity oxygen/nitrogen radicals: cell injury and disease. Springer, pp 119-124

Kang BR, Kim H, Nam SH, Yun EY, Kim SR, Ahn MY (2012) CopA3 peptide from Copris tripartitus induces apoptosis in human leukemia cells via a caspase-independent pathway. BMB Rep 45(2):85-90

Kim IW, Lee JH, Kwon YN, Yun EY, Nam SH, Ahn MY, Kang DC, Hwang JS (2013) Anticancer activity of a synthetic peptide derived from harmoniasin, an antibacterial peptide from the ladybug Harmonia axyridis. Int J Oncol 43(2):622-628. doi:10.3892 /ijo.2013.1973

Koczulla AR, Bals R (2003) Antimicrobial peptides: current status and therapeutic potential. Drugs 63(4):389-406

Korotkov K, Garcia R (2012) Computerized analysis of pigmented skin lesions: a review. Artif Intell Med 56(2):69-90

Lee E, Rosca EV, Pandey NB, Popel AS (2011) Small peptides derived from somatotropin domain-containing proteins inhibit blood and lymphatic endothelial cell proliferation, migration, adhesion and tube formation. Int J Biochem Cell Biol 43(12):1812-1821

Lee JH, Kim I-W, Kim S-H, Yun E-Y, Nam S-H, Ahn M-Y (2015) Anticancer activity of CopA3 dimer peptide in human gastric cancer cells. BMB Rep 48(6):324

Mader JS, Hoskin DW (2006) Cationic antimicrobial peptides as novel cytotoxic agents for cancer treatment. Expert Opin Investig Drugs 15(8):933-946

Mai JC, Mi Z, Kim S-H, Ng B, Robbins PD (2001) A proapoptotic peptide for the treatment of solid tumors. Cancer Res 61(21): 7709-7712

McGregor DP (2008) Discovering and improving novel peptide therapeutics. Curr Opin Pharmacol 8(5):616-619

McPhee JB, Scott MG, Hancock RE (2005) Design of host defence peptides for antimicrobial and immunity enhancing activities. Comb Chem High Throughput Screen 8(3):257-272

Merrifield RB, Juvvadi P, Andreu D, Ubach J, Boman A, Boman HG (1995) Retro and retroenantio analogs of cecropin-melittin hybrids. Proc Natl Acad Sci U S A 92(8):3449-3453

Monincova L, Budesinsky M, Slaninova J, Hovorka O, Cvacka J, Voburka Z (2010) Novel antimicrobial peptides from the venom of the eusocial bee Halictus sexcinctus (Hymenoptera: Halictidae) and their analogs. Amino Acids 39:763-775

Moore AJ, Devine DA, Bibby MC (1994) Preliminary experimental anticancer activity of cecropins. Pept Res 7(5):265-269

Mulder KC, Lima LA, Miranda VJ, Dias SC, Franco OL (2013) Current scenario of peptide-based drugs: the key roles of cationic antitumor and antiviral peptides. Front Microbiol 4:321. doi:10.3389 /fmicb.2013.00321

Ogden S, Telfer NR (2009) Skin cancer. Medicine 37(6):305-308

Oren Z, Shai Y (1998) Mode of action of linear amphipathic alpha-helical antimicrobial peptides. Biopolymers 47(6):451-463. doi:10.1002 /(SICI)1097-0282(1998)47:6

Palanki R, Arora S, Tyagi N, Rusu L, Singh AP, Palanki S, Carter JE, Singh S (2015) Size is an essential parameter in governing the UVBprotective efficacy of silver nanoparticles in human keratinocytes. BMC Cancer 15(1):636

Papo N, Shai Y (2005) Host defense peptides as new weapons in cancer treatment. Cell Mol Life Sci 62(7-8):784-790. doi:10.1007/s00018005-4560-2

Poon IK, Baxter AA, Lay FT, Mills GD, Adda CG, Payne JA, Phan TK, Ryan GF, White JA, Veneer PK (2014) Phosphoinositide-mediated oligomerization of a defensin induces cell lysis. Elife 3:e01808. doi:10.7554/eLife.01808

Pouny Y, Shai Y (1992) Interaction of D-amino acid incorporated analogs of pardaxin with membranes. Biochemistry 31(39):9482-9490 
Rahnamaeian M (2011) Antimicrobial peptides: modes of mechanism, modulation of defense responses. Plant Signal Behav 6(9):1325-1332

Rahnamaeian M, Vilcinskas A (2015) Short antimicrobial peptides as cosmetic ingredients to deter dermatological pathogens. Appl Microbiol Biotechnol 99(21):8847-8855

Rahnamaeian M, Cytrynska M, Zdybicka-Barabas A, Dobslaff K, Wiesner J, Twyman RM, Zuchner T, Sadd BM, Regoes RR, Schmid-Hempel P, Vilcinskas A (2015) Insect antimicrobial peptides show potentiating functional interactions against Gramnegative bacteria. Proc Biol Sci 282(1806). doi:10.1098 /rspb.2015.0293

Rahnamaeian M, Cytrynska M, Zdybicka-Barabas A, Vilcinskas A (2016) The functional interaction between abaecin and poreforming peptides indicates a general mechanism of antibacterial potentiation. Peptides 78:17-23. doi:10.1016/j.peptides.2016.01.016

Raz A, Bucana C, McLellan W, Fidler I (1980) Distribution of membrane anionic sites on B16 melanoma variants with differing lung colonising potential. Nature 284(5754):363-364

Reddy K, Yedery R, Aranha C (2004) Antimicrobial peptides: premises and promises. Int J Antimicrob Agents 24(6):536-547

Riedl S, Rinner B, Asslaber M, Schaider H, Walzer S, Novak A, Lohner K, Zweytick D (2011a) In search of a novel target — phosphatidylserine exposed by non-apoptotic tumor cells and metastases of malignancies with poor treatment efficacy. Biochim Biophys Acta 1808(11):2638 2645. doi:10.1016/j.bbamem.2011.07.026

Riedl S, Zweytick D, Lohner K (2011b) Membrane-active host defense peptides - challenges and perspectives for the development of novel anticancer drugs. Chem Phys Lipids 164(8):766-781. doi:10.1016/j. chemphyslip.2011.09.004

Robinson JK (2005) Sun exposure, sun protection, and vitamin D. JAMA 294(12):1541-1543

Rodrigues EG, Dobroff AS, Cavarsan CF, Paschoalin T, Nimrichter L, Mortara RA, Santos EL, Fázio MA, Miranda A, Daffre S, Travassos LR (2008) Effective topical treatment of subcutaneous murine B16F10-Nex2 melanoma by the antimicrobial peptide gomesin. Neoplasia 10(1):61-68

Rogers HW, Weinstock MA, Harris AR, Hinckley MR, Feldman SR, Fleischer AB, Coldiron BM (2010) Incidence estimate of nonmelanoma skin cancer in the United States, 2006. Arch Dermatol 146(3):283-287

Rosca EV, Koskimaki JE, Rivera CG, Pandey NB, Tamiz AP, Popel AS (2011) Anti-angiogenic peptides for cancer therapeutics. Curr Pharm Biotechnol 12(8):1101-1116

Saido-Sakanaka H, Ishibashi J, Momotani E, Amano F, Yamakawa M (2004) In vitro and in vivo activity of antimicrobial peptides synthesized based on the insect defensin. Peptides 25(1):19-27

Sanderson BJ, Ferguson LR, Denny WA (1996) Mutagenic and carcinogenic properties of platinum-based anticancer drugs. Mutat Res 355(1-2):59-70

Schweizer F (2009) Cationic amphiphilic peptides with cancer-selective toxicity. Eur J Pharmacol 625(1-3):190-194. doi:10.1016/j. ejphar.2009.08.043

Shang B, Cao Z, Zhou Q (2012) Progress in tumor vascular normalization for anticancer therapy: challenges and perspectives. Front Med 6(1): $67-78$

Sharma S (1992) Melittin resistance: a counterselection for ras transformation. Oncogene 7(2):193-201

Siegel R, Ma J, Zou Z, Jemal A (2014) Cancer statistics, 2014. CA Cancer J Clin 64(1):9-29

Silva ON, Porto WF, Migliolo L, Mandal SM, Gomes DG, Holanda HH, Silva RS, Dias SC, Costa MP, Costa CR (2012) Cn-AMP1: a new promiscuous peptide with potential for microbial infections treatment. Pept Sci 98(4):322-331

Slaninova J, Mlsova V, Kroupova H, Alan L, Tumova T, Monincova L (2012) Toxicity study of antimicrobial peptides from wild bee venom and their analogs toward mammalian normal and cancer cells. Peptides 33(1):18-26

Stern RS (2010) Prevalence of a history of skin cancer in 2007: results of an incidence-based model. Arch Dermatol 146(3):279-282

Stewart BW, Wild CP (2014) World Cancer Report 2014 vol 5. World Health Organization, $\mathrm{p} 14$

Teixeira V, Feio MJ, Bastos M (2012) Role of lipids in the interaction of antimicrobial peptides with membranes. Prog Lipid Res 51(2):149-177

Telfer N, Colver G, Morton C (2008) Guidelines for the management of basal cell carcinoma. Br J Dermatol 159(1):35-48

Thayer AM (2011) Improving peptides, small firms develop better peptide drug candidates to expand this pharmaceutical class and attract big pharma partners. Chemical \& Engineering News 89(22):13-20

Tonk M, Cabezas-Cruz A, Valdés JJ, Rego RO, Chrudimská T, Strnad M, Śíma R, Bell-Sakyi L, Franta Z, Vilcinskas A, Grubhoffer L, Rahnamaeian M (2014) Defensins from the tick Ixodes scapularis are effective against phytopathogenic fungi and the human bacterial pathogen Listeria grayi. Parasit Vectors 7:554. doi: 10.1186/s13071014-0554-y

Tosteson M, Holmes S, Razin M, Tosteson D (1985) Melittin lysis of red cells. J Membr Biol 87(1):35-44

Utsugi T, Schroit AJ, Connor J, Bucana CD, Fidler IJ (1991) Elevated expression of phosphatidylserine in the outer membrane leaflet of human tumor cells and recognition by activated human blood monocytes. Cancer Res 51(11):3062-3066

Vera RE, Lamberti MJ, Rivarola VA, Rumie Vittar NB (2015) Developing strategies to predict photodynamic therapy outcome: the role of melanoma microenvironment. Tumour Biol 36(12): 9127-9136. doi:10.1007/s13277-015-4059-x

Wachinger M, Kleinschmidt A, Winder D, von Pechmann N, Ludvigsen A, Neumann M, Holle R, Salmons B, Erfle V, Brack-Werner R (1998) Antimicrobial peptides melittin and cecropin inhibit replication of human immunodeficiency virus 1 by suppressing viral gene expression. J Gen Virol 79(Pt 4):731-740

Wang C, Chen T, Zhang N, Yang M, Li B (2009) Lü X (2009) Melittin, a major component of bee venom, sensitizes human hepatocellular carcinoma cells to tumor necrosis factor-related apoptosis-inducing ligand (TRAIL)-induced apoptosis by activating CaMKII-TAK1$\mathrm{JNK} / \mathrm{p} 38$ and inhibiting IKB $\alpha$ kinase-NFkB. J Biol Chem 284(6): 3804-3813

Wang C, Chen YW, Zhang L, Gong XG, Zhou Y, Shang DJ (2016) Melanoma cell surface-expressed phosphatidylserine as a therapeutic target for cationic anticancer peptide, temporin-1CEa. J Drug Target 24(6):548-556. doi:10.3109/1061186X.2015.1113539

Wang C, Zhou Y, Li S, Li H, Tian L, Wang H, Shang D (2013) Anticancer mechanisms of temporin-1CEa, an amphipathic alpha-helical antimicrobial peptide, in Bcap-37 human breast cancer cells. Life Sci 92(20-21):1004-1014. doi:10.1016/j.lfs.2013.03.016

Wiesner J, Vilcinskas A (2010) Antimicrobial peptides: the ancient arm of the human immune system. Virulence 1(5):440-464. doi:10.4161 /viru.1.5.12983

Winder D, Günzburg WH, Erfle V, Salmons B (1998) Expression of antimicrobial peptides has an antitumour effect in human cells. Biochem Biophys Res Commun 242(3):608-612

Wu Y, Xia L, Li J, Zhang F (2015) CecropinXJ inhibits the proliferation of human gastric cancer BGC823 cells and induces cell death in vitro and in vivo. Int J Oncol 46(5):2181-2193

Xia L, Zhang F, Liu Z, Ma J, Yang J (2013) Expression and characterization of cecropinXJ, a bioactive antimicrobial peptide from Bombyx mori (Bombycidae, Lepidoptera) in Escherichia coli. Exp Therapeut Med 5(6):1745-1751. doi:10.3892/etm.2013.1056

Xia L, Wu Y, Kang S, Ma J, Yang J, Zhang F (2016) CecropinXJ, a silkworm antimicrobial peptide, induces cytoskeleton disruption in esophageal carcinoma cells. Acta Biochim Biophys Sin (Shanghai) 46(10):867-876 
Xiao YC, Huang YD, Xu PL, Zhou ZQ, Li XK (2006) Pro-apoptotic effect of cecropin $\mathrm{AD}$ on nasopharyngeal carcinoma cells. Chin Med J 119(12):1042-1046

Yamada M, Nakamura K, Saido-Sakanaka H, Asaoka A, Yamakawa M, Yamamoto Y, Koyama Y, Hikosaka K, Shimizu A, Hirota Y (2005) Therapeutic effect of modified oligopeptides from the beetle Allomyrina dichotoma on methicillin-resistant Staphylococcus aureus (MRSA) infection in mice. J Vet Med Sci 67(10):1005-1011

Yeaman MR, Yount NY (2003) Mechanisms of antimicrobial peptide action and resistance. Pharmacol Rev 55(1):27-55. doi:10.1124 /pr.55.1.2

Zahreddine H, Borden KL (2013) Mechanisms and insights into drug resistance in cancer. Front Pharmacol 4:28. doi:10.3389 /fphar.2013.00028
Zhang W, Li J, Liu LW, Wang KR, Song JJ, Yan JX, Li ZY, Zhang BZ, Wang R (2010) A novel analog of antimicrobial peptide Polybia-MPI, with thioamide bond substitution, exhibits increased therapeutic efficacy against cancer and diminished toxicity in mice. 31(10):1832-1838

Zhang WM, Lai ZS, He MR, Xu G, Huang W, Zhou DY (2003) Effects of the antibacterial peptide cecropins from Chinese oak silkworm, Antheraea pernyi on 1, 2-dimethylhydrazine-induced colon carcinogenesis in rats. Di Yi Jun Yi Da Xue Xue Bao 23(10):1066-1068

Zhang Z, Zhang H, Peng T, Li D, Xu J (2016) Melittin suppresses cathepsin $\mathrm{S}$-induced invasion and angiogenesis via blocking of the VEGF-A/VEGFR-2/MEK1/ERK1/2 pathway in human hepatocellular carcinoma. Oncol Lett 11(1):610-618

Zhu Y, Cheng Y, Luo RC, Li AM (2015) Aspirin for the primary prevention of skin cancer: a meta-analysis. Oncol Lett 9(3):1073-1080 